\title{
Cervical Cancer pT1a2 TNM Finding v8
}

National Cancer Institute

\section{Source}

National Cancer Institute. Cervical Cancer pT 1a2 TNM Finding v8. NCI Thesaurus. Code C139712.

Invasive cervical carcinoma with measured stromal invasion of more than $3.0 \mathrm{~mm}$ and not more than $5.0 \mathrm{~mm}$, with a horizontal spread of $7.0 \mathrm{~mm}$ or less. (from AJCC 8th Ed.) 